\title{
Diyarimizdiki bir qism yärnamiliri häqqidä. Pékin, Millätlär näshriyati, 2006, 341 p. [Â propos des toponymes d'une partie de notre pays]
}

\section{Alexandre Papas}

\section{(2) OpenEdition}

Journals

Édition électronique

URL : http://journals.openedition.org/abstractairanica/39838

DOI : 10.4000/abstractairanica.39838

ISSN : 1961-960X

Éditeur :

CNRS (UMR 7528 Mondes iraniens et indiens), Éditions de l'IFRI

\section{Édition imprimée}

Date de publication : 15 mai 2011

ISSN : 0240-8910

\section{Référence électronique}

Alexandre Papas, « Diyarimizdiki bir qism yärnamiliri häqqidä. Pékin, Millätlär näshriyati, 2006, 341 p. [À propos des toponymes d'une partie de notre pays] », Abstracta Iranica [En ligne], Volume 31 | 2011, document 307, mis en ligne le 11 octobre 2012, consulté le 27 septembre 2020. URL : http:// journals.openedition.org/abstractairanica/39838; DOI : https://doi.org/10.4000/abstractairanica. 39838

Ce document a été généré automatiquement le 27 septembre 2020.

Tous droits réservés 


\section{Diyarimizdiki bir qism yärnamiliri häqqidä. Pékin, Millätlär näshriyati, 2006, 341 p. [À propos des toponymes d'une partie de notre pays]}

\section{Alexandre Papas}

1 Écrit par une philologue et un géographe (auteur d'une excellente étude sur les anciennes routes caravanières du Xinjiang publiée en 2000), cet ouvrage analyse la toponymie des différentes zones de la Région autonome ouïgoure du Xinjiang. Le premier chapitre (p. 1-102) détaille les noms de lieux d'Urumchi : murs d'enceinte, rues principales, quartiers, ateliers importants, bâtiments, lieux de culte, cimetières mais également, au niveau orographique et géologique, montagnes, lits de rivière, lacs, etc. Le second chapitre (p. 104-181) décrit les contreforts des Tian Shan (Tängritagh en ouïgour) et le Xinjiang nord-oriental dont les villes de Turpan, Pichan et Qomul. Alors que le troisième chapitre (p. 183-240) dresse une liste des principaux toponymes de la Djoungarie et de l'Ili, la quatrième section (p. 242-341) étudie le Xinjiang méridional : le Tarim d'abord puis les grandes oasis et leur district (Kashgar, Aqsu, Khotan, Korla, Artush). Une bizarrerie notable : Yarkand n'apparaît pas. On aurait souhaité davantage de données issues des sources arabes, turques et persanes. 
INDEX

Thèmes : 15.3. Asie centrale

\section{AUTEURS}

ALEXANDRE PAPAS

CNRS - Paris 